\title{
In Silico Study of Plant Polyphenols' Interactions with VP24-Ebola Virus Membrane-associated Protein
}

\author{
Sebastian Pleško, ${ }^{1}$ Helena Volk, ${ }^{2}$ Miha Lukšič ${ }^{1}$ and Črtomir Podlipnik ${ }^{1, *}$ \\ ${ }^{1}$ Faculty of Chemistry and Chemical Technology, University of Ljubljana, Večna pot 113, SI-1000 Ljubljana, Slovenia \\ ${ }^{2}$ Biotechnical Faculty, University of Ljubljana, Jamnikarjeva 101, SI-1000, Ljubjana, Slovenia \\ *Corresponding author: E-mail: crtomir.podlipnik@fkkt.uni-lj.si
}

Received: 08-03-2015

Dedicated to prof. Jože Koller on the occasion of his $70^{\text {th }}$ birthday.

\begin{abstract}
The Zaire Ebola viral protein VP24 selectively inhibits nuclear import of STAT1 and as such blocks interferon-induced antiviral responses vital for cell's emergency. Inhibition of VP24 with small molecule inhibitor may neutralize the threatening action of Ebola virus. We performed molecular docking of compounds from a selected small library of plant polyphenols on to VP24. Our research shows that 1,2,3,6-tetragalloyl glucose, epigallocatechin gallate, chlorogenic acic, oleuropein and miquelianin represent promising leads for further studies.
\end{abstract}

Keywords: Ebola virus, VP24, KPNA5, STAT1, plant polyphenols, molecular docking

\section{Introduction}

Ebola virus (EBOV) - a single stranded RNA filovirus - is one of the deadliest viruses in the world. Case fatality rates of the current 2014 outbreak in West Africa are more than $70 \% .^{1-3}$ Transmission of EBOV is predominatly via physical contacts with the bodily fluids of infected people or corpses, and can be limited by a proper combination of an early diagnosis, contact tracing, isolation of patients, infection control and safe burial. ${ }^{4-6}$

The infection is characterized by the immune system suppression and a systematic inflammatory response, followed by the collapse of the vascular and immune systems, and multi-organ failure. The patient dies from a combination of dehydration, massive bleeding and shock. There is currently no prophylactic cure for the hemorrhagic fever caused by EBOV. However, there is some conflicting clinical evidence that antibodies isolated from survived patients may be effective in the treatment of the infection caused by EBOV. ${ }^{7,8}$

The EBOV genome consists of seven genes: nucleoprotein (NP), viral proteins (VP) 24, 30, 35 and 40, glycoprotein (GP) and RNA-dependent RNA polymerase. ${ }^{9} \mathrm{GP}$ is a transmembrane protein that mediates binding to the cell receptor and fusion during the virus' entry.
Thus GP represents an ideal target for the neutralizing antibodies. ${ }^{10}$ On the other hand the EBOV GP protein mutates regularly during the outbreaks and it is almost impossible to find a universal antibody that would antagonize the EBOV GP. ${ }^{3,11}$ Another problem connected with antibodies is their thermal stability. They need to be kept at low temperatures. Ensuring such "cold-chain" during transportation and storage represents a logistic nightmare in the third world countries. ${ }^{12}$ Alongside with antibodies also carbohydrate binding proteins (lectines) may be used as potential agents against Ebola. Recent research by Garrison et al. has shown that cyanobacterial lectin scytovirin displays in vitro and in vivo activity against Zaire Ebola virus. ${ }^{13}$

Secondary matrix protein VP24 incorporated in EBOV is one of the proteins that play a crucial role in Ebola virus disease pathology. Moreover, several studies have recognized VP24 as a major virulence factor. ${ }^{14-16}$ Zhang et al. reported that VP24 directly binds to STAT $1 .{ }^{17}$ STAT1 is a transcription factor involved in the up-regulation of genes due to a signal by different interferons. ${ }^{18}$ Garcia-Dorival et al. used an approach based on high affinity purification coupled with a label-free mass spectrometry for the identification of possible cellular proteins that are likely to interact with VP24. ${ }^{19}$ 
Their bioinformatics analysis located approximately 50 cell proteins to be targeted by VP24. They established that karyopherin 5 (KPNA5, also named importin- $\alpha$ ), lamin B1, VDAC-1 and ATP1A1 have a predominant tendency to bind with VP24. Our study focuses on the identification of small molecule inhibitors that would block interaction between the EBOV protein VP24 and KPNA5. The background of this strategy is described in the following paragraph.

The binding of interferon (IFN) to the IFN receptors located on the surface of the host cell is the key event that initiates adaptive immune response to viral infection. The binding of interferon to its receptor leads to the activation of Janus tyrosine kinases (JAK1 and TYK2), which are involved in the activation of STAT1 protein. The phosphorylated STAT1 (PY-STAT1) forms dimers that interact with KPNA5. The KPNA5:STAT1:STAT1 complex is then translocated to the nucleus where STAT1 transcription factor activates expression of several hundred interferon stimulated genes (Figure 1). In the case of the EBOV infection, STAT1 is normally phosphorylated and also forms a dimeric state. However, STAT1:STAT1 is unable to form a complex with KPNA5 which is antagonized with VP24. Therefore STAT1:STAT1 cannot enter the cell nucleus, as in the case of a common viral infection. In other words, VP24 blocks interferon initiated cell's emergency response. The measured affinity between KPNA5 and VP24 is in the low nanomolar range $\left(\mathrm{K}_{\mathrm{d}}=1-10 \mathrm{nM}\right)$ in contrast to STAT1:STAT1 which binds to KPNA5 with a micromolar dissociation constant. ${ }^{20,21}$ To sum up, the EBOV protein VP24 selectively inhibits nuclear import of STAT1 and as such blocks interferon-induced antiviral responses; this action of VP24 is shown schematically in Figure $1 .^{15}$

\section{Methods}

\section{1. Energy Analysis of VP24:KPNA5C Complex}

The FoldX software ${ }^{22}$ a module of YASARA Structure ${ }^{23}$ was used for the energy analysis of the complex between viral VP24 and human KPNA5C (C terminal of

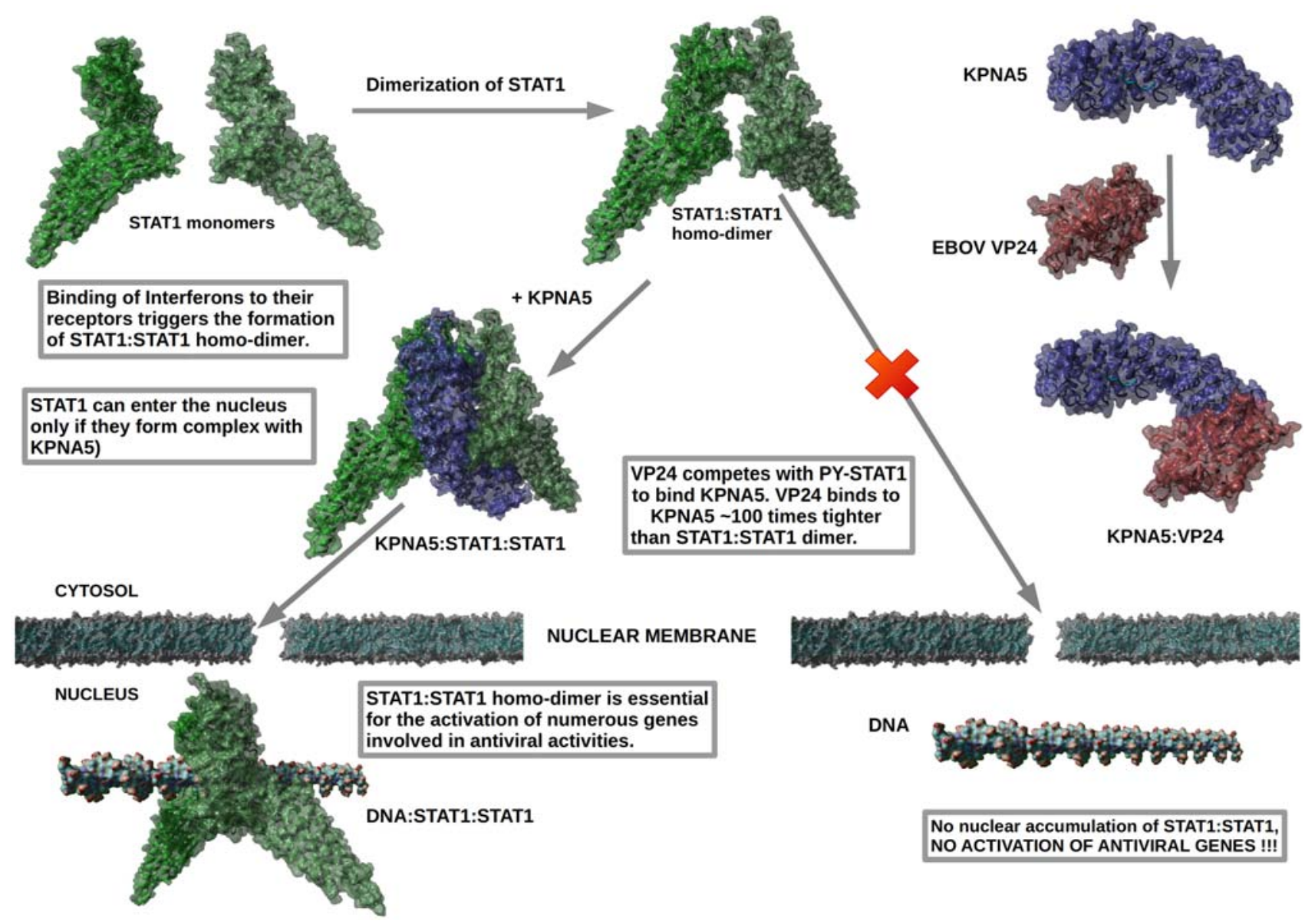

Figure 1 Transfer of STAT1 homo-dimer to the nucleus in the case of common (left) and EBOV (right) infection. VP24 acts as an interferon antagonist by blocking the interaction between KPNA5 and STAT1:STAT1 homo-dimer which is required for the translocation of STAT1:STAT1 across the nucleus membrane. 


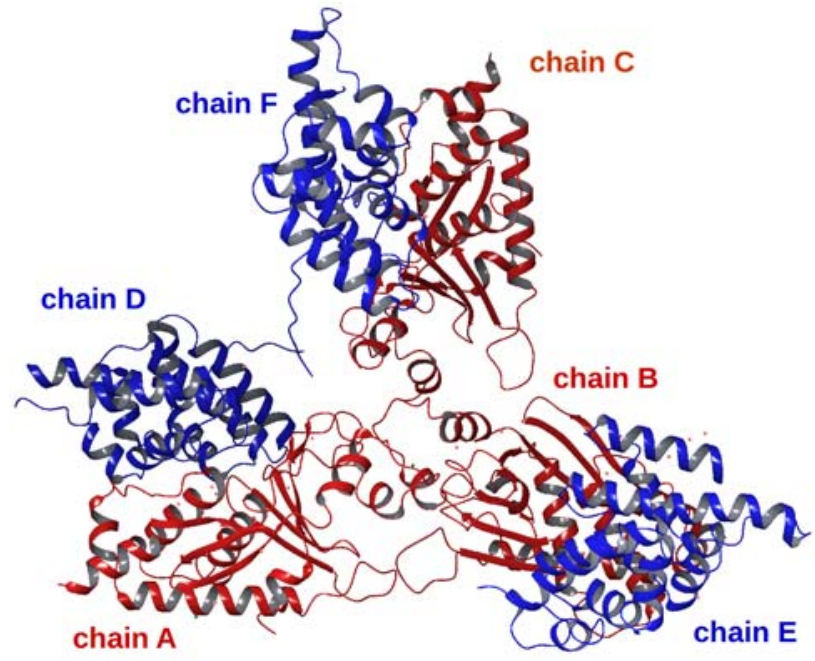

Figure 2: The complex between the viral VP24 and human KPNA5C (PDB-ID:4U2X).

KPNA5), retrieved from RCSB PDB database with corresponding PDB-ID:4U2X. In this particular complex VP24 protein exists in a trimer form, and each VP24 (chain A, B, C) interacts with a corresponding KPNA5C fragment (chain D, E, F). ${ }^{21}$ The structure was imported as a PDB file in the workspace of YASARA Structure GUI. Before computing the energy analysis of the complex, the latter was repaired with FoldX's RepairPDB script to correct non-standard angles or distances, to optimize side chains of the protein and to set proper protonation state of the residues. The figure of the repaired complex is shown in Figure 2.

\section{2. Molecular Docking Protocol}

Our docking protocol consists of four phases. (1) In the first phase, the Schrodinger's Protein Preparation Wizard (PPW) ${ }^{24}$ was used for the preparation of the protein. The preparation of the protein using PPW is a semi-automatic process which includes several steps. In the first step, the protein structure (PDB-ID:4U2X) is downloaded from the protein data bank (PDB) and placed into the workspace of Maestro GUI. Only the first VP24:KPNA5 complex composed of chain A (VP24) and chain D (KPNA5) was retained. The remaining four chains were deleted from GUI. Then PPW was used to correct bond orders in protein and to apply hydrogens to all atoms. This step is followed by the neutralization of side chains, which are not close to the binding site and do not participate in salt bridges, finally by the restrain minimization of the protein structure. To ensure integrity of the X-ray structure, the minimization was stopped when the RMSD of the heavy atoms between coordinates of the current and starting structures fell below $0.2 \AA$. At the end of the modeling process, the Chain $\mathrm{D}$, which belongs to KPNA5, was deleted.
(2) In the next phase we located binding sites and generated interaction grids that are required for the docking study. $\mathrm{Xu}$ et al. located three important sites on the VP24's surface responsible for interaction with KPNA5: the first cluster (Site 1) consists of residues L115, L121, W125, T128, T129, N130, T131, N135, R137, T138 and R140; the second cluster (Site 2) contains the following residues D124, T128, T129, Q184, N185 and H186; and the third cluster (Site 3) includes residues L201, Q202, E203, P204, D205, K206 and S207. ${ }^{21}$ Three interaction grids were generated by Receptor Grid Generator (Glide ver. 5.8). The position of each grid was defined as a centroid of clustered residues. Van der Waals scaling factor was set to be 0.85 (the slightly reduced value of the van der Waals scaling factor introduced some plasticity of the binding site in the model).

(3) The ligand library was prepared from the initial SMILES $\operatorname{codes}^{25}$ with LigPrep (ver. 2.5). LigPrep is a Schrödinger's utility that combines tools for generating 3D structures from linear SMILES code and/or 2D SDF representation. Several options of these structures such as: tautomers, stereo-isomers, and protonation states generated by LigPrep were used to perform virtual screening of ligands' library against each of the three VP24 binding sites. The library of 18 candidate ligands (Figure 3) was constructed as a fine selection out of a larger library of various plant compounds. All the ligands' ionization states were at physiological conditions.

(4) In our case, Schrödinger's Glide (ver. 5.6) in XP (extra precision) mode was used to perform molecular docking. ${ }^{26}$ The three binding sites on the same surface of the VP24 with the docked epigalocatchin gallate are shown as an example in Figure 4.

\section{3. Induced fit Docking (IFD) of the Ligands on the VP24 Binding Sites}

Initially, the ligands (see Figure 3 ) were docked on the rigid VP24 protein by using a softened-potential in the Glide program with the van der Waals scaling of 0.5 for protein and 0.5 for the ligands. We used the top 10 poses of each ligand to sample protein plasticity with an extensive side chain conformational search and subsequent minimization. Finaly, re-docking with the default settings (scaling factor for protein and ligand was set to be 1.0 and 0.8 , respectively) was performed for all complexes from the previous step and the Glide XP score was used for scoring all docking calculations. ${ }^{27,28}$

\section{Results and Discussion}

It has been found that an interaction of VP24 with the KPNA5 plays an important role in the progression of the Ebola virus disease. ${ }^{15}$ The structure of the complex of Ebola VP24 protein with KPNA5 (PDB-ID: 4U2X; Fig 


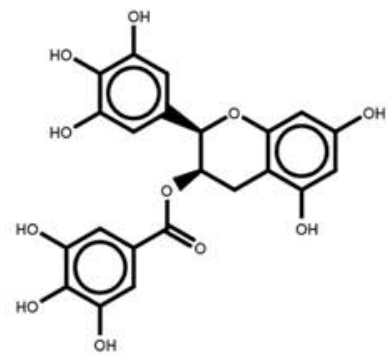

epigallocatehin gallate (EGCG)

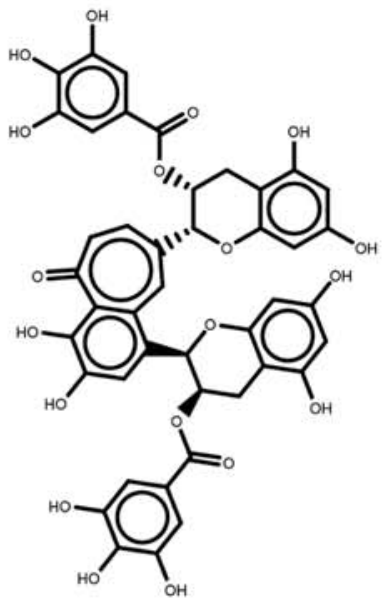

theaflavin-3.3'-diqallate

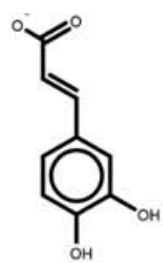

caffeic acid<smiles>O=c1c(O)c(-c2cc(O)c(O)c(O)c2)oc2cc(O)cc(O)c12</smiles><smiles>O=C([O-])[C@H]1O[C@@H](Oc2c(-c3ccc(O)c(O)c3)oc3cc(O)cc(O)c3c2=O)[C@H](O)[C@@H](O)[C@H]1O</smiles>

miquelianin

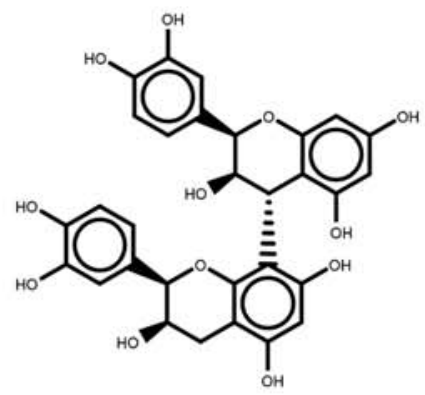

procyanidin B2<smiles>O=c1c(O)c(-c2ccc(O)cc2)oc2cc(O)cc(O)c12</smiles>

kaempherol

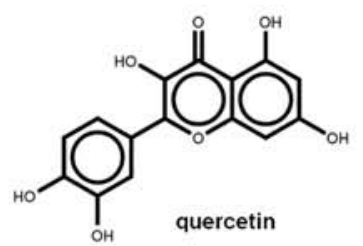<smiles>O=C(/C=C/c1ccc(O)c(O)c1)O[C@H]1C[C@@](O)(C(=O)[O-])C[C@H](O)[C@H]1O</smiles>

chlorogenic acid<smiles>COc1cc(/C=C/C(=O)CC(=O)/C=C/c2ccc(O)c(OC)c2)ccc1O</smiles>
curcumin<smiles>O=C(OC[C@H]1O[C@@H](OC(=O)c2cc(O)c(O)c(O)c2)[C@H](O)[C@H](OC(=O)c2cc(O)c(O)c(O)c2)[C@@H]1O)c1cc(O)c(O)c(O)c1</smiles>

$1,2,3,6$ tetragalloyl glucose (TGG)<smiles>C/C=C1/[C@H](C[C@H]2O[C@H](CO)[C@@H](O)[C@H](O)[C@H]2O)OC=C(C(=O)OC)[C@H]1CC(=O)OCCc1ccc(O)c(O)c1</smiles>

oleuropein<smiles>Oc1ccc(C=Cc2cc(O)cc(O)c2)cc1</smiles><smiles>O=C(CCc1ccc(O)cc1)c1c(O)cc(O)cc1O</smiles>

phloretin<smiles>O=C(C=Cc1ccc(O)c(O)c1)O[C@@H](Cc1ccc(O)c(O)c1)C(=O)[O-]</smiles>
rosmarinic acid

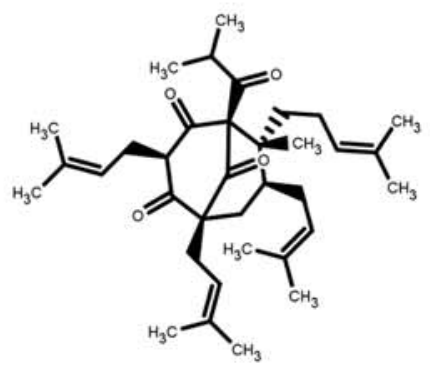

hyperforin

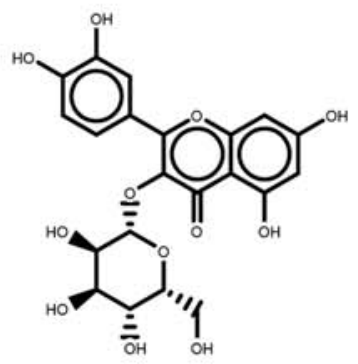

hyperoside

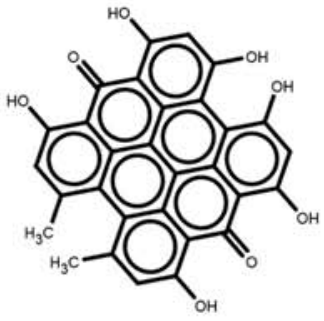

hypericin

Figure 3: Library of natural compounds selected for virtual screening of the VP24 protein. 


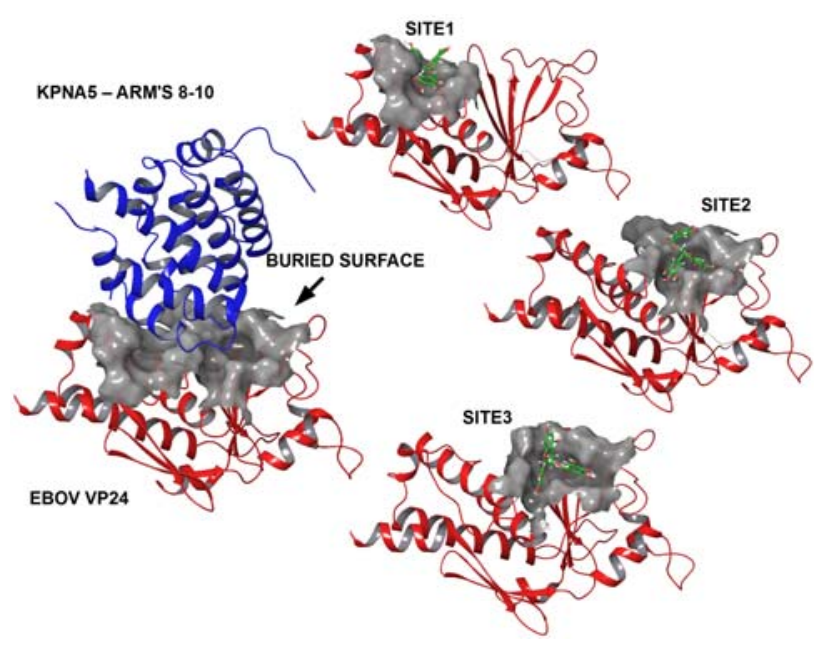

Figure 4: Detection of binding sites based on the interaction between EBOV VP24 protein and KPNA5.

2) has been resolved only recently. ${ }^{21}$ In the first step of our study the FoldX program was used to determinate interactions between different units of the PDB structure. The results of this analysis are given in Table 1 . These results indicate that FoldX's $\Delta \mathrm{G}$ of interaction between VP24 and its counterpart protein KPNA5C is around $-102 \mathrm{~kJ} / \mathrm{mol}$. The results in table 1 show that VP24 preferably exists as a dimer rather than a trimer due to an unfavorable $(+4.6 \mathrm{~kJ} / \mathrm{mol})$ interaction between chain $\mathrm{C}$ and the chains A and B (see Figure 2). From figure 2 it is evident that the binding sites of KPNA5 are located at
Table 1: (a) The interaction free energy of the complex's chain with the rest of the VP24:KPNA5C complex. (b) The interaction free energy for each of the complex chain with the rest of the VP24 trimer.

\begin{tabular}{ccc}
\hline Chain & $\begin{array}{c}\Delta \mathbf{G}(\mathbf{a}) \\
(\mathbf{k J} / \mathbf{m o l})\end{array}$ & $\begin{array}{c}\Delta \mathbf{G}(\mathbf{b}) \\
(\mathbf{k J} / \mathbf{m o l})\end{array}$ \\
\hline A (VP24) & -164.4 & -44.8 \\
B (VP24) & -168.6 & -54.0 \\
C (VP24) & -96.7 & 4.6 \\
D (KPNA5C) & -110.0 & -111.3 \\
E (KPNA5C) & -104.2 & -104.2 \\
F (KPNA5C) & -91.2 & -91.2 \\
\hline
\end{tabular}

each of the single chains of the VP24's trimer. The binding sites are more or less energetically equivalent. $\mathrm{Ne}-$ vertheless, research by Zhang et al. has shown that VP24 in the context of whole cell lysate is predominately monomeric. ${ }^{29}$

In Table 2 the results of Glide and Induced Fit docking are presented. In both cases the Glide XP scoring function was used for the estimation of the ligands' binding affinity to each of the three binding sites of VP24. All three binding sites are solvent exposed. The bioavailability data calculated with the Schrödinger's Qikprop (ver. 3.5) are also shown alongside the docking results.

Docking results showed that VP24 has relevant affinity to several plant polyphenols such as epigallocatechin gallate (EGCG), 1,2,3,6-tetragalloyl glucose (1,2,3,6TGG), and theaflavin-3,3'-digallate. These compounds are the main active ingredients of green and fermented

Table 2: Docking Scores for natural ligands bound to three different sites of VP24 protein.

\begin{tabular}{|c|c|c|c|c|c|c|c|c|c|c|}
\hline \multirow[t]{2}{*}{ Compound } & \multicolumn{6}{|c|}{ GlideXP Score (kJ/mol) } & \multicolumn{4}{|c|}{ Bio-availability properties } \\
\hline & \multicolumn{2}{|c|}{ Site 1} & \multicolumn{2}{|c|}{ Site 2} & \multicolumn{2}{|c|}{ Site 3} & \multirow{2}{*}{$\begin{array}{c}\text { HB } \\
8 / 9\end{array}$} & \multirow{2}{*}{$\frac{\log \mathbf{P}}{-0.21}$} & \multirow{2}{*}{$\frac{\text { Bio. }}{Y}$} & \multirow{2}{*}{$\frac{\text { Lip. }}{2}$} \\
\hline epigallocatechin gallate & -30.1 & $(-39.7)$ & -29.3 & $(-43.5)$ & -23.8 & $(-33.5)$ & & & & \\
\hline procyanidin $\mathrm{B} 2$ & -30.1 & $(-39.3)$ & -30.5 & $(-43.9)$ & -18.0 & $(-39.3)$ & $10 / 11$ & 0.22 & $\mathrm{~N}$ & 3 \\
\hline $1,2,3,6-\mathrm{TGG}$ & -52.7 & $(-44.3)$ & -42.7 & $(-57.7)$ & -41.0 & $(-49.0)$ & $13 / 20$ & -3.0 & $\mathrm{~N}$ & 3 \\
\hline theaflavin-3,3'-digallate & -38.5 & $(-44.7)$ & -40.2 & $(-43.5)$ & -27.2 & $(-36.0)$ & $11 / 16$ & 1.02 & $\mathrm{~N}$ & 3 \\
\hline caffeic acid & -26.8 & $(-26.8)$ & -20.9 & $(-15.9)$ & -19.2 & $(-18.0)$ & $3 / 4$ & 0.56 & $\mathrm{Y}$ & 0 \\
\hline Phloretin & -26.4 & $(-23.0)$ & -24.7 & $(-36.8)$ & -18.0 & $(-31.8)$ & $2 / 3$ & 2.13 & $\mathrm{Y}$ & 0 \\
\hline chlorogenic acid & -28.5 & $(-43.1)$ & -31.4 & $(-36.0)$ & -30.1 & $(-31.8)$ & $6 / 9$ & -0.27 & $\mathrm{Y}$ & 1 \\
\hline Resveratrol & -21.3 & $(-18.8)$ & -21.3 & $(-20.9)$ & -16.7 & $(-20.5)$ & $3 / 3$ & 2.00 & $\mathrm{Y}$ & 0 \\
\hline Curcumin & -32.6 & $(-32.6)$ & -24.3 & $(-25.1)$ & -16.7 & $(-25.1)$ & $3 / 7$ & 2.90 & $\mathrm{Y}$ & 0 \\
\hline rosmarinic acid & -33.1 & $(-34.3)$ & -31.8 & $(-33.9)$ & -21.3 & $(-25.1)$ & $5 / 7$ & 1.16 & $\mathrm{Y}$ & 0 \\
\hline Oleuropein & -28.9 & $(-34.7)$ & -25.1 & $(-40.2)$ & -19.7 & $(-24.7)$ & $6 / 17$ & -0.55 & $\mathrm{~N}$ & 3 \\
\hline Kaempherol & -20.9 & $(-22.6)$ & -22.2 & $(-23.8)$ & -24.3 & $(-21.8)$ & $3 / 5$ & 1.2 & $\mathrm{Y}$ & 0 \\
\hline Quercetin & -29.3 & $(-29.7)$ & -26.4 & $(-27.2)$ & -28.5 & $(-28.0)$ & $4 / 5$ & 0.38 & $\mathrm{Y}$ & 0 \\
\hline Hyperforin & -12.1 & $(-21.3)$ & -11.3 & $(-17.6)$ & -7.5 & $(-14.6)$ & $0 / 8$ & 6.67 & $\mathrm{~N}$ & 2 \\
\hline Hypericin & -27.6 & $(-33.4)$ & -18.4 & $(-16.7)$ & -24.7 & $(-4.2)$ & $2 / 5$ & 3.2 & $\mathrm{~N}$ & 2 \\
\hline Hyperoside & -37.7 & $(-44.3)$ & -26.8 & $(-33.1)$ & -34.7 & $(-45.2)$ & $7 / 14$ & -1.3 & $\mathrm{~N}$ & 2 \\
\hline Miquelianin & -27.6 & $(-41.8)$ & -25.9 & $(-36.8)$ & -28.9 & $(-23.0)$ & $6 / 13$ & -0.96 & $\mathrm{~N}$ & 2 \\
\hline Myricetin & -28.9 & $(-26.3)$ & -26.8 & $(-33.5)$ & -29.3 & $(-31.0)$ & $5 / 6$ & -0.28 & Y & 1 \\
\hline
\end{tabular}

Induced fit docking results are placed in brackets; HB - Estimated number of hydrogen bonds that would be donated/accepted by the solute from water molecules in an aqueous solution; $\log \mathrm{P}$ - the logarithm of the partition coefficient between water and 1-octanol; Bio. - bioavailability (Chemicalize ${ }^{30}$ ); Lip. - deviation from Lipinski rule of five. ${ }^{31}$ 
(black) tea, ${ }^{32}$ green apple extract, ${ }^{33}$ pomegranate,${ }^{34}$ etc. Numerous scientific reports state that regular consumption of the mentioned polyphenols can have a beneficial effect on human health. ${ }^{32,35}$ For example, EGCG the main component of green tea can reduce the risk of diabetes type II $^{36}$ and Alzheimer's disease. ${ }^{37}$ Moreover, as an efficient trap for radicals, it may even have an anticancer protective function. By the inhibition of ARF activated toxic

\section{1,2,3,6-TGG (IFD GlideScore XP = -57.7 kJ/mol)}

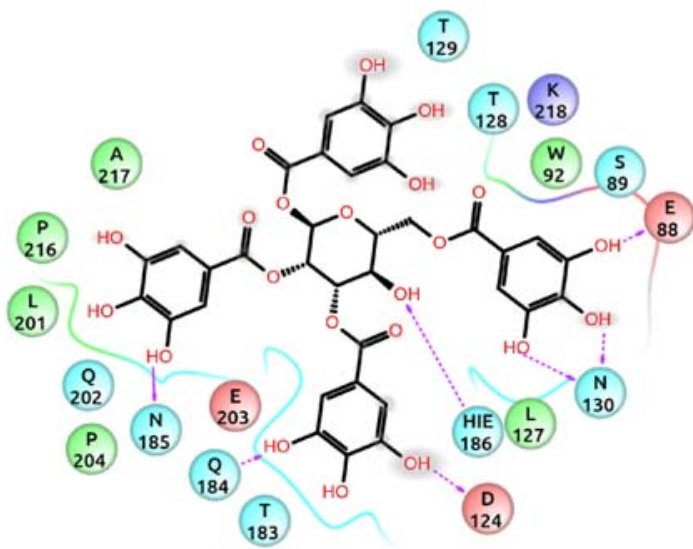

EGCG (IFD GlideScore XP = $-43.5 \mathrm{~kJ} / \mathrm{mol}$ )
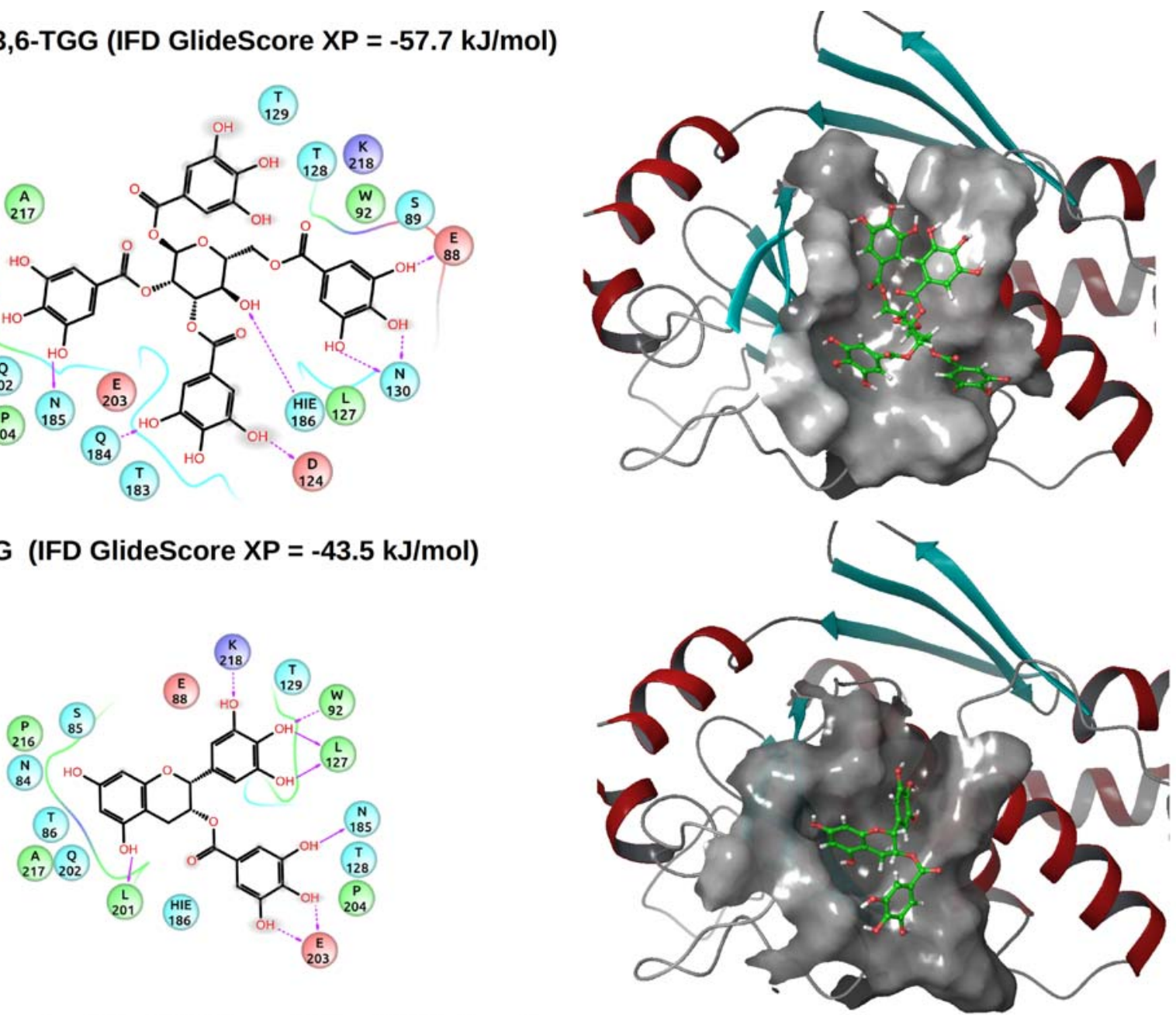

oleuropein (IFD GlideScore XP = $\mathbf{- 4 0 . 2 ~ k J / m o l ) ~}$
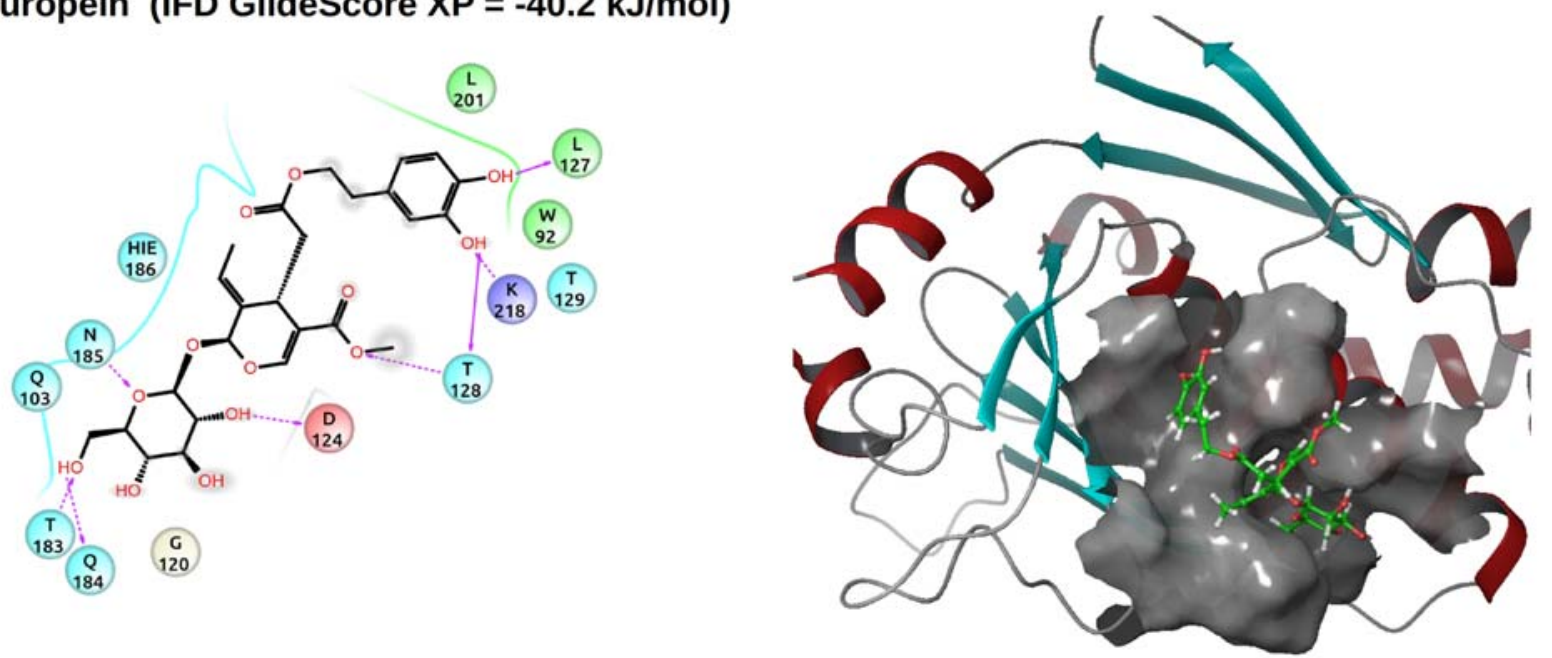

Figure 5: Interaction maps (left) and poses (right) of 1,2,3,6-TGG, EGCG and oleuropein within binding Site 2 of Ebola VP24. 
unit A of the Cholera toxin the 1,2,3,6-TGG can inhibit fluid accumulation caused by the toxin. ${ }^{38}$ Due to a promising score and phyto-pharmaceutical relevance of EGCG and 1,2,3,6-TGG we decided to check their interactions with VP24 in detail. IFD of 1,2,3,6-TGG to VP24's Site 2 gave the lowest binding energy $(-57.7 \mathrm{~kJ} / \mathrm{mol})$ measured by Glide XP score. It is evident from Figure 5 that 1,2,3,6TGG nicely fits the extensive regions of the shallow and solvent exposed VP24's Site 2 binding pocket. Each of the four galloyl moieties attached to a glucose scaffold serves as tentacles, which with its hydroxyl groups search for hydrogen bonding contacts with their counterpart residues of the binding pocket. Altogether, seven hydrogen bonding contacts of the ligand with the receptor's residues are shown: E88, D124, $2 \times \mathrm{N} 130, \mathrm{~N} 135$, E184 and H186. It is also evident from Table 2 that 1,2,3,6-TGG fits in Sites 1 and 3 but the interaction evaluated by Glide Score is a little bit weaker. The IFD Glide XP score for EGCG to Site 2 of VP2 4 was $-43.5 \mathrm{~kJ} / \mathrm{mol}$; also, this ligand fits nicely in the binding site. The total number of hydrogen contacts was 7 (W92, $2 \times$ L127, N185, L201, 2×E203, K218), the number was the same as in the case of $1,2,3,6-$ TGG. Despite the promising scores, it is very difficult to classify these compounds as promising leads for drug design, especially due to numerous ester groups which are easily hydrolyzed in vivo and also most of the compounds failed the Lipinski's rule of five criteria, ${ }^{31}$ which is an empirically evaluated criteria of druglikeness or ability of certain compound to be membrane permeable. Therefore additional work will be needed to find suitable modifications of the before mentioned compounds to make them more bioavailable.

chlorogenic acid (IFD GlideScore XP = -43.1 kJ/mol)
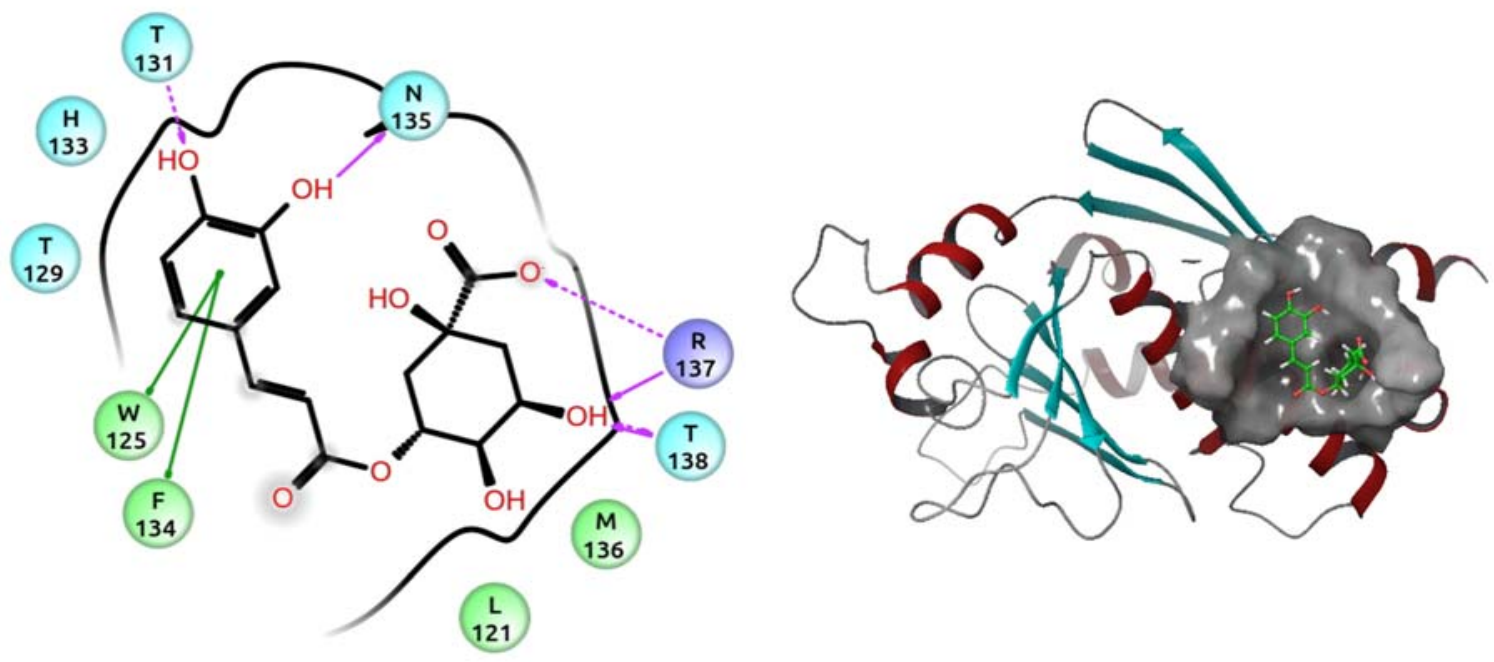

miquelianin (IFD GlideScore XP $=-41.8 \mathrm{~kJ} / \mathrm{mol}$ )
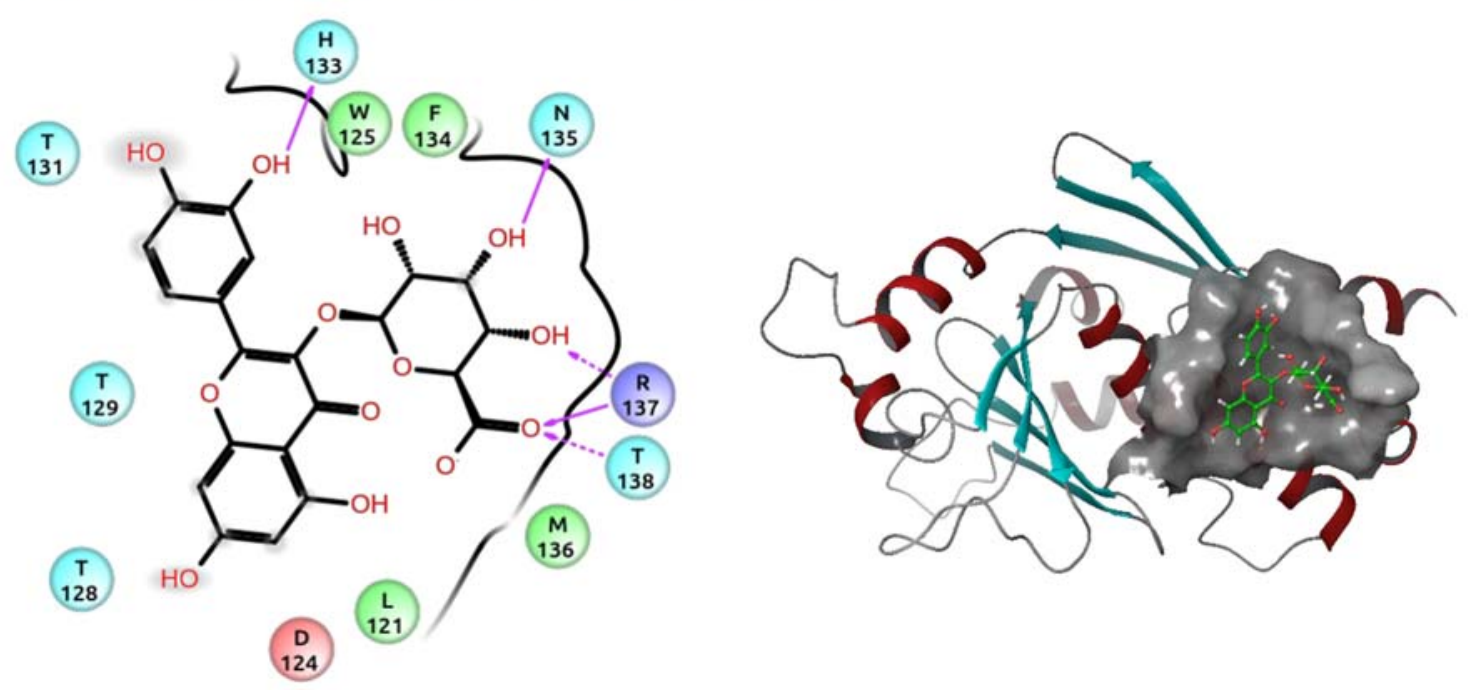

Figure 6: Interaction maps (left) and poses (right) of chlorogenic acid and miquelianin within binding Site 1 of Ebola VP24. 
Caffeic acid, phloretin, chlorogenic acid, resveratrol, curcumin, and rosmarinic acid form a set of compounds isolated from plants that are frequently found as active ingredients of phytopharmaceutical formulations with a wide range of action. ${ }^{39-41}$ Of these six compounds, chlorogenic acid has the highest predicted affinity to VP24 (IFD Glide XP Score $=-43.5 \mathrm{~kJ} / \mathrm{mol}$ ). Our in silico study showed that chlorogenic acid targets Site 1 of VP24 (Figure 6), the binding of chlorogenic acid with VP24 is supported by six hydrogen bonding contacts (T131, N135, $2 \times \mathrm{R} 137, \mathrm{~T} 137)$ and also by two $\pi-\pi$ stacking interactions (W125, F134). Chlorogenic acid could be a promising lead compound for further drug design, since it has a good bioavailability along with good in silico binding properties to VP24.

Oleuropein, kaempherol and quercetin are active ingredients in olive leaves. ${ }^{16}$ In silico studies by Kasmi et al. have shown that all three compounds can bind with Ebola proteins VP24 and VP30. ${ }^{42}$ Our study showed that oleuropein might be the best binder to VP24 among all of the three mentioned ingredients in olive leaves. The best binding affinity of oleuropein to VP24 was obtained by using IFD on Site 2. Glide XP Score for the best pose was -40.2 $\mathrm{kJ} / \mathrm{mol}$.

Another set of compounds consisted of hyperforin, hypericine, hyperoside, miquelianin, and myricetin, which are active ingredients of St. John's wort (Hypericum perforatum) ${ }^{43}$ Docking results showed a promising in silico activity against VP24 for hyperoside (Glide XP Score $=-44.3 \mathrm{~kJ} / \mathrm{mol}$ ) and miquelianin (Glide XP Score $=$ $-41.8 \mathrm{~kJ} / \mathrm{mol}$ ). The binding mode of miquelianin and its interaction map to VP24 Site 1 is shown in Figure 6. The interaction of miquelianin and VP24 Site 1 is stabilized with five hydrogen bonds (H133, N135, $2 \times$ R137, T138). It can be seen in Figure 6 that quercetin moiety of the compound is more exposed to the solvent and less involved into the hydrogen bonded network than the quinic acid moiety. The good bioavailability of miquelianin determined by in vitro experiment sets this compound as a promising lead for further drug design. ${ }^{44}$

\section{Conclusions}

In our opinion, VP24 is the optimal drug target for curing EBOV infection as it has been shown recently by Warren et $a l .{ }^{45}$ They have shown that RNA interference drug targeting VP24 protect rhesus monkeys against lethal EBOV infection. Unfortunately, the recent paper from Kugelman et al. ${ }^{11}$ discovered great genomic drift of the EBOV genome during the current West African outbreak, whereas the mutations of the VP24 protein only happened outside the identified active sites. ${ }^{46}$ Thus the RNA interference drugs are not an optimal choice of therapy. That's the reason why our main objective was to find a small molecule that would antagonize directly the interaction bet- ween the Ebola VP24 protein and the human protein KPNA5, which is required for the translocation of STAT1:STAT1 dimer across nuclear membrane to nucleus, where STAT1 transcription factor initiates an expression of interferon stimulated genes. A library of 17 wellknown plant polyphenols and a hyperforin was constructed for virtual screening purposes. The analysis of Glide docking results showed that 7 compounds $(1,2,3,6-\mathrm{TGG}$, hyperoside, theaflavin-3,3'-digallate, procyanidin B2, chlorogenic acid, and miquelianin) have affinity to VP24 measured with Glide XP score that surpasses -41.8 $\mathrm{kJ} / \mathrm{mol}$. According to our results, 1,2,3,6-TGG (Glide XP score $=-57.7 \mathrm{~kJ} / \mathrm{mol}$ ) could be the best inhibitor among all of the screened compounds. From the results collected in Table 2 it can be seen that the plasticity of the receptor, using IFD, generally improves the docking results. Despite the encouraging results of our virtual screening experiments we need to consider the bioavailability of the suggested compounds. This puts chlorogenic acid as our favorite compound for VP24 inhibition. In order to exclude false positives (compounds that have good virtual score but they are not active in vivo) in vitro evaluation of the binding affinities of the best binders to VP24 should be performed in the future.

\section{Acknowledgments}

This work was supported by the Slovenian Research Agency (ARRS) through the research program P1-0201. S.P. acknowledges the support of the Slovenian Science Foundation (SZF). Acknowledgments to Mirzet Čuskić for fruitful discussions and Alexandra $\mathrm{H}$. for proof-reading.

\section{References}

1. H. Branswell, Sci Am 2015, 312, 42-49. http://dx.doi.org/10.1038/scientificamerican0315-48

2.WHO_Ebola_Response_Team, $N$ Engl J Med 2014, 371, 1481-1495.

3. S. K. Gire, A. Goba, K. G. Andersen, R. S. Sealfon, D. J. Park, L. Kanneh, S. Jalloh, M. Momoh, M. Fullah, G. Dudas, S. Wohl, L. M. Moses, N. L. Yozwiak, S. Winnicki, C. B. Matranga, C. M. Malboeuf, J. Qu, A. D. Gladden, S. F. Schaffner, X. Yang, P. P. Jiang, M. Nekoui, A. Colubri, M. R. Coomber, M. Fonnie, A. Moigboi, M. Gbakie, F. K. Kamara, V. Tucker, E. Konuwa, S. Saffa, J. Sellu, A. A. Jalloh, A. Kovoma, J. Koninga, I. Mustapha, K. Kargbo, M. Foday, M. Yillah, F. Kanneh, W. Robert, J. L. Massally, S. B. Chapman, J. Bochicchio, C. Murphy, C. Nusbaum, S. Young, B. W. Birren, D. S. Grant, J. S. Scheiffelin, E. S. Lander, C. Happi, S. M. Gevao, A. Gnirke, A. Rambaut, R. F. Garry, S. H. Khan, P. C. Sabeti, Science 2014, 345, 1369-1372. http://dx.doi.org/10.1126/science.1259657

4. M. T. Osterholm, K. A. Moore, N. S. Kelley, L. M. Brosseau, 
G. Wong, F. A. Murphy, C. J. Peters, J. W. LeDuc, P. K. Russell, M. Van Herp, J. Kapetshi, J. J. Muyembe, B. K. Ilunga, J. E. Strong, A. Grolla, A. Wolz, B. Kargbo, D. K. Kargbo, P. Formenty, D. A. Sanders, G. P. Kobinger, MBio 2015, 6, e00137_00115.

5. E. M. Leroy, P. Rouquet, P. Formenty, S. Souquiere, A. Kilbourne, J. M. Froment, M. Bermejo, S. Smit, W. Karesh, R. Swanepoel, S. R. Zaki, P. E. Rollin, Science 2004, 303, 387-390. http://dx.doi.org/10.1126/science.1092528

6. A. Pandey, K. E. Atkins, J. Medlock, N. Wenzel, J. P. Townsend, J. E. Childs, T. G. Nyenswah, M. L. NdeffoMbah, A. P. Galvani, Science 2014, 346, 991-995. http://dx.doi.org/10.1126/science.1260612

7. G. G. Olinger, Jr., J. Pettitt, D. Kim, C. Working, O. Bohorov, B. Bratcher, E. Hiatt, S. D. Hume, A. K. Johnson, J. Morton, M. Pauly, K. J. Whaley, C. M. Lear, J. E. Biggins, C. Scully, L. Hensley, L. Zeitlin, Proc Natl Acad Sci U S A 2012, 109, 18030-18035. http://dx.doi.org/10.1073/pnas.1213709109

8. T. R. Kreil, Emerg Infect Dis 2015, 21, 521-523. http://dx.doi.org/10.3201/eid2103.141838

9. E. Muhlberger, Future virology 2007, 2, 205-215. http://dx.doi.org/10.2217/17460794.2.2.205

10. C. D. Murin, M. L. Fusco, Z. A. Bornholdt, X. Qiu, G. G. Olinger, L. Zeitlin, G. P. Kobinger, A. B. Ward, E. O. Saphire, Proc Natl Acad Sci U S A 2014, 111, 17182-17187. http://dx.doi.org/10.1073/pnas.1414164111

11. J. R. Kugelman, M. Sanchez-Lockhart, K. G. Andersen, S. Gire, D. J. Park, R. Sealfon, A. E. Lin, S. Wohl, P. C. Sabeti, J. H. Kuhn, G. F. Palacios, MBio 2015, 6, e02227-02214.

12. O. S. Kumru, S. B. Joshi, D. E. Smith, C. R. Middaugh, T. Prusik, D. B. Volkin, Biologicals 2014, 42, 237-259. http://dx.doi.org/10.1016/j.biologicals.2014.05.007

13. A. R. Garrison, B. G. Giomarelli, C. M. Lear-Rooney, C. J. Saucedo, S. Yellayi, L. R. Krumpe, M. Rose, J. Paragas, M. Bray, G. G. Olinger, Jr., J. B. McMahon, J. Huggins, B. R. O'Keefe, Antiviral Res 2014, 112, 1-7. http://dx.doi.org/10.1016/j.antiviral.2014.09.012

14. M. Mateo, C. Carbonnelle, O. Reynard, L. Kolesnikova, K. Nemirov, A. Page, V. A. Volchkova, V. E. Volchkov, Journal of Infectious Diseases 2011, 204, S1011-S1020. http://dx.doi.org/10.1093/infdis/jir338

15. S. P. Reid, L. W. Leung, A. L. Hartman, O. Martinez, M. L. Shaw, C. Carbonnelle, V. E. Volchkov, S. T. Nichol, C. F. Basler, J Virol 2006, 80, 5156-5167. http://dx.doi.org/10.1128/JVI.02349-05

16. S. H. Omar, Sci Pharm 2010, 78, 133-154. http://dx.doi.org/10.3797/scipharm.0912-18

17. A. P. Zhang, Z. A. Bornholdt, T. Liu, D. M. Abelson, D. E. Lee, S. Li, V. L. Woods, Jr., E. O. Saphire, PLoS Pathog 2012, 8, e1002550. http://dx.doi.org/10.1371/journal.ppat.1002550

18. M. G. Katze, Y. He, M. Gale, Jr., Nat Rev Immunol 2002, 2, 675-687. http://dx.doi.org/10.1038/nri888

19. I. Garcia-Dorival, W. Wu, S. Dowall, S. Armstrong, O. Touzelet, J. Wastling, J. N. Barr, D. Matthews, M. Carroll, R.
Hewson, J. A. Hiscox, J Proteome Res 2014, 13, 5120-5135. http://dx.doi.org/10.1021/pr500556d

20. J. Nardozzi, N. Wenta, N. Yasuhara, U. Vinkemeier, G. Cingolani, J Mol Biol 2010, 402, 83-100. http://dx.doi.org/10.1016/j.jmb.2010.07.013

21. W. Xu, M. R. Edwards, D. M. Borek, A. R. Feagins, A. Mittal, J. B. Alinger, K. N. Berry, B. Yen, J. Hamilton, T. J. Brett, R. V. Pappu, D. W. Leung, C. F. Basler, G. K. Amarasinghe, Cell Host Microbe 2014, 16, 187-200. http://dx.doi.org/10.1016/j.chom.2014.07.008

22. J. Schymkowitz, J. Borg, F. Stricher, R. Nys, F. Rousseau, L. Serrano, Nucleic Acids Res 2005, 33, W382-388. http://dx.doi.org/10.1093/nar/gki387

23. E. Krieger, G. Vriend, Bioinformatics 2014, 30, 2981-2982. http://dx.doi.org/10.1093/bioinformatics/btu426

24. G. M. Sastry, M. Adzhigirey, T. Day, R. Annabhimoju, W. Sherman, J Comput Aided Mol Des 2013, 27, 221-234. http://dx.doi.org/10.1007/s10822-013-9644-8

25. D. Weininger, J Chem Inf Comput Sci 1988, 28, 31-36. http://dx.doi.org/10.1021/ci00057a005

26. R. A. Friesner, R. B. Murphy, M. P. Repasky, L. L. Frye, J. R. Greenwood, T. A. Halgren, P. C. Sanschagrin, D. T. Mainz, J Med Chem 2006, 49, 6177-6196.

http://dx.doi.org/10.1021/jm051256o

27. C. Podlipnik, F. Tutino, A. Bernardi, P. Seneci, J Mol Graph Model 2010, 29, 309-320.

http://dx.doi.org/10.1016/j.jmgm.2010.09.008

28. W. Sherman, H. S. Beard, R. Farid, Chem Biol Drug Des 2006, 67, 83-84. http://dx.doi.org/10.1111/j.1747-0285.2005.00327.x

29. J. Baell, M. A. Walters, Nature 2014, 513, 481-483. http://dx.doi.org/10.1038/513481a

30. C. Southan, A. Stracz, J Cheminform 2013, 5, 20. http://dx.doi.org/10.1186/1758-2946-5-20

31. C. A. Lipinski, Drug Discov Today Technol 2004, 1, 337-341. http://dx.doi.org/10.1016/j.ddtec.2004.11.007

32. Y. Wang, C.-T. Ho, Journal of Agricultural and Food Chemistry 2009, 57, 8109-8114. http://dx.doi.org/10.1021/jf804025c

33. T. Shoji, Y. Akazome, T. Kanda, M. Ikeda, Food Chem Toxicol 2004, 42, 959-967.

http://dx.doi.org/10.1016/j.fct.2004.02.008

34. R. F. Wang, W. D. Xie, Z. Zhang, D. M. Xing, Y. Ding, W. Wang, C. Ma, L. J. Du, J Nat Prod 2004, 67, 2096-2098. http://dx.doi.org/10.1021/np0498051

35. R. Tsao, Nutrients 2010, 2, 1231-1246. http://dx.doi.org/10.3390/nu2121231

36. H. M. Kim, J. Kim, Diabetes Metab J 2013, 37, 173-175. http://dx.doi.org/10.4093/dmj.2013.37.3.173

37. J. Bieschke, J. Russ, R. P. Friedrich, D. E. Ehrnhoefer, H. Wobst, K. Neugebauer, E. E. Wanker, Proc Natl Acad Sci U $S$ A 2010, 107, 7710-7715. http://dx.doi.org/10.1073/pnas.0910723107

38. C. Podlipnik, Acta Chim. Slov. 2009, 56, 156-165.

39. W. Y. Huang, Y. Z. Cai, Y. Zhang, Nutr Cancer 2010, 62, 1-20. http://dx.doi.org/10.1080/01635580903191585 
40. M. Skrt, E. Benedik, C. Podlipnik, N. P. Ulrih, Food Chem 2012, 135, 2418-2424.

http://dx.doi.org/10.1016/j.foodchem.2012.06.114

41. E. Benedik, M. Skrt, C. Podlipnik, N. P. Ulrih, Food Chem Toxicol 2014, 74, 1-8.

http://dx.doi.org/10.1016/j.fct.2014.08.012

42. K. Yassine, International Journal of Innovation and Applied Studies 2014, 8, 1566-1573.

43. A. Smelcerovic, M. Spiteller, S. Zuehlke, J Agric Food Chem 2006, 54, 2750-2753. http://dx.doi.org/10.1021/jf0527246
44. G. Juergenliemk, K. Boje, S. Huewel, C. Lohmann, H.-J. Galla, A. Nahrstedt, Planta Med 2003, 69, 1013-1017. http://dx.doi.org/10.1055/s-2003-45148

45. T. K. Warren, C. A. Whitehouse, J. Wells, L. Welch, A. E. Heald, J. S. Charleston, P. Sazani, S. P. Reid, P. L. Iversen, S. Bavari, MBio 2015, 6, e02344-02314.

http://dx.doi.org/10.1128/mBio.02344-14

46. A. S. Olabode, X. Jiang, D. L. Robertson, S. C. Lovell, BioRxiv 2015.

\section{Povzetek}

Protein 42 virusa Ebola selektivno inhibira transport STAT1 v celično jedro ter tako prepreči z interferoni induciran protivirusni odziv, ki je ključen za reakcijo celice na okužbo. VP24 Inhibicija z molekulo inhibitorja lahko omili škodljivo delovanje virusa Ebola na človeški organizem. Izvedli smo molekulski doking spojin iz knjižnice naravnih rastlinskih polifenolov s proteinom VP24. Pokazali smo, da 1,2,3,6-tetragaloil glukoza, epigalokatehin galat, klorogena kislina, oleuropein ter miquelianin predstavljajo potencialne obetajoče spojine vodnice. 